Article

\title{
Implementation of General Sustainability Objectives as Tools to Improve the Environmental Performance of Industry
}

\author{
Richard Almgren * $*$ and Olof Hjelm \\ Department of Management and Engineering, Environmental Technology and Management, \\ Linköping University, SE-58183 Linköping, Sweden; olof.hjelm@liu.se \\ * Correspondence: richard.almgren@liu.se; Tel.: +46705688112
}

Citation: Almgren, R.; Hjelm, O. Implementation of General

Sustainability Objectives as Tools to Improve the Environmental

Performance of Industry.

Sustainability 2021, 13, 8144. https://

doi.org/10.3390/su13158144

Academic Editor: João Carlos de Oliveira Matias

Received: 17 May 2021

Accepted: 6 July 2021

Published: 21 July 2021

Publisher's Note: MDPI stays neutral with regard to jurisdictional claims in published maps and institutional affiliations.

Copyright: (c) 2021 by the authors. Licensee MDPI, Basel, Switzerland. This article is an open access article distributed under the terms and conditions of the Creative Commons Attribution (CC BY) license (https:/ / creativecommons.org/licenses/by/ $4.0 /)$.

\begin{abstract}
This article examines the implementation of the Swedish national environmental quality objectives and discusses what can be learned for the equivalent process for the set of global UN 2030 goals (SDGs), established in 2015. The empirical basis is a study on 50 large companies in Sweden and their use of these objectives in their policy formulation. The SDGs are crafted with a broader approach than the Swedish national environmental quality objectives. Therefore, the SDGs probably better reflect the agenda of the business community since they have a global character, cover the whole spectrum of important sustainability issues and provide a mutual agenda for the business community worldwide. More than 90 percent of the large companies in the study have explicitly committed themselves to the SDGs, only 1-2 years after they were published, whereas similar commitments hardly exist for the national environmental quality objectives, even 20 years after their establishment. A large majority of the large companies in this study know about the SDGs, have actively endorsed them, and started to adjust their activities accordingly. In the end, the results of these endorsements remain to be seen.
\end{abstract}

Keywords: agenda 2030; sustainability goals; national environmental quality objectives; industry; integration; implementation

\section{Introduction}

The basic idea behind environmental policy in the business sector is to make companies change their agendas to take environmental considerations into account [1-4]. Many different environmental policy instruments have been developed for this purpose, mostly to advocate for certain behavior by using different kinds of legislation, such as environmental permitting systems and restrictions on the production and use of certain chemicals and other products. A comprehensive review of research on environmental policy instruments was made by the OECD [4]. Since then, a number of similar studies have been performed (for example, [5-11]). Other ways to improve environmental performance are to change the incentives in the market, such as by public procurement, financial support or subsidies, trading of emissions like the trading system of greenhouse gases EU ETS [12] in the EU or by fees. Furthermore, more soft incentives commonly used are improved knowledge, such as to initiate education and training, perform information campaigns, support the use of life cycle analysis and other means to improve the environmental characteristics of products $[13,14]$, ask for declarations of the use of energy, support the use of labelling of products with certain features, certify persons or organizations, such as environmental management systems based on ISO 14001 of international environmental management standard [15], and encourage transparency by systematic reporting, such as reports based on the Global Reporting Initiative (GRI) [16].

Belonging to the same group of soft policy instruments are non-legislated general policy objectives or systems targeted at a broad audience. These are implemented entirely as a voluntary action. It is not unusual for governments to use objectives, targets and 
goals as a component in their environmental acquis. For example, the UN has previously published goals on sustainability, such as Agenda 21 [17], Global Compact [18,19] and the Millennium Goals [20]. Within the EU environmental acquis can be found 87 non-binding objectives and 159 legally binding targets [21]. Similar objectives have been established to support the work in international conventions, such as CLRTAP [22], HELCOM [23] and OSPAR [24]. However, it is quite unusual to use such a broad set of objectives and targets at a national level as stated by OECD [25].

This article deals with the national environmental quality objectives implemented in Sweden during the years 1999-2005 [26-29], analyzes the implementation of those objectives and examines whether they affected the environmental performance of industry. Based on lessons learnt from that, we aim to identify factors that can increase the effectiveness of implementing the United Nations 2030 goals (SDGs), published in 2015 [30]. It remains to be seen whether the SDGs will substantially influence the sustainability ambitions in companies or if they will become another example of ineffective attempts to guide further global development. According to Hajer et al. [31], the SDGs have the potential to become a powerful political vision that can support the urgently needed global transition to a shared and lasting prosperity. However, they also highlight the risk of the SDGs falling short because of the illusion that top-down steering by governments and intergovernmental organizations alone can address global problems. In the end, the question of when a business is truly sustainable needs to be addressed [32]. Moreover, in practice, the concept of societal transformation takes on largely different meanings for different actors across societies, for example, regarding pace, scope, goal and governability of transformations [33].

The rest of the article is structured as follows: We start by identifying the main properties of the SDGs and the national Swedish environmental quality objectives. This is followed by a description of the methodology used in studying the implementation of the two sets of objectives in Sweden. After the results are presented, we discuss how companies relate to the national quality objectives and if there are lessons learnt for the implementation of the SDGs. Finally, the conclusions are presented, and policy implications are discussed.

\section{General Sustainability and Environmental Objectives}

In this section, we elaborate on the two studied sets of general objectives and give an overview of the literature guiding the study and its conclusions. The global sustainable development goals (SDGs) were introduced as Agenda 2030 by the General Assembly of the United Nations (UN) at its summit in September 2015 [30]. The goals are expected to reflect what needs to be done to shift the world to a sustainable and resilient path. The 17 goals are further developed with 169 targets. According to the agenda, the goals and targets will stimulate action over the next 15 years. All countries and stakeholders are expected to implement this plan, but no specific mechanism for implementing the plan has been established. The implementation phase is delegated to the various member states of the UN, which are expected to establish their own action plans. Accordingly, governmental committees have been established in several countries, including Sweden, to support the implementation of the 17 goals. The activities are supposed to be based on communication and capacity building.

It is a huge challenge to describe such a complex area as sustainable development in just a few sentences or goals. The Brundtland Commission managed in its book Our Common Future to capture the concept into a short sentence basically to take the future generation into account and thereby balance economic, environmental and social issues [34]. Further, it should be noted that other similar sets of objectives have been established internationally before. Examples of this are the EU Environment Action Program [35], the first one issued in 1973. Furthermore, a comprehensive list of other visions of sustainable development is available in an annex to ISO 26000:2010 [36]. 
Another system, the Swedish environmental quality objectives, was gradually established during the period 1999-2005 as guidance for the environmental policies in the decades to come. The set of objectives was initially prepared by the Swedish Environmental Protection Agency, SwEPA [37]. The purpose of the objectives and their design can be found in nine government bills [26-29,38-42]. This approach to environmental policies was adopted by the Parliament with a broad majority [43]. Sixteen national objectives and 72 interim targets were established. At a later stage, the interim targets were replaced by 24 milestones [39]. None of the mentioned objectives or interim targets/milestones are prescriptive such as would be the case if they were legislated. The objectives were supposed to serve as guidance in the application of permit in accordance with legislation. The time span, one generation, was defined as 21 years in the period 1999-2020 [26]. Initially, the objectives and targets were of two kinds, long-term ("one generation") and short-term (10 years). In addition, regional and local objectives were supposed to support the national objectives [27].

From the bill on interim targets [27], four purposes of the system of environmental quality objectives can be identified:

- Describe the state of the Swedish environment;

- Integrate environmental concerns in all sectors;

- Strengthen knowledge of environmental issues;

- Provide a tool for interaction in international for a.

Since the set of national environmental quality objectives was established already in 1999, the system has undergone many changes, keeping the basic purposes unchanged. From a corporate perspective, which is the perspective of this article, the second and third purposes listed above are of most interest. Purpose one and four are primarily aimed at governmental bodies, and efforts to meet these two purposes are omitted from this article. When it comes to integration, the Swedish Government [27] provides the explanation that there is a need for a common vision, that all actors need to contribute and that legislation as an incentive is not enough.

The 16 environmental quality objectives are essentially of two kinds: firstly, the ones that in positive terms describe a scientific issue or threat, and secondly, those that provide a utopian landscape objective [44,45]. To better understand the purpose of the set of environmental quality objectives and to fit the purpose of this article, we have categorized them in the perspectives concerning types of objective (mainly pollution-related and mainly land use-related) and geographical distribution of causes (global, continental and national; see Table 1). Most of the land use-related environmental quality objectives are related to measures to be taken mainly by national, regional and local governments, while the pollution-related objectives have the business community as an important target group. All the causes of the environmental issues addressed by the pollution-related objectives have a global or continental distribution, whereas the causes for most of the land-use objectives have a national character. However, it must be noted that there are overlaps in the presented structure in the sense that some objectives belong to more than one category. For example, the environmental quality objective Clean Air has a global and national pollution-related as well as a land-use-related dimension in addition to the categorization in Table 1. Other such examples are the objectives of A Varied Agricultural Landscape and Sustainable Forests, where the business community is also an important target group.

The national environmental objectives have been frequently reviewed mostly within a national perspective, although they are phrased within an international context [46-67].

From previous studies, some key features can be identified to make objectives and targets of this kind successful. They shall be clearly phrased [56,68-74] be suitable to the target group [2,44,71,72], include an implementation mechanism [2,71], be possible to evaluate [73,75], include a specified deadline [72] and be known to the target group [76]. In addition, to achieve the objectives and targets, industry needs to build resilient infrastructure, promote inclusive and sustainable industrialization and foster innovation [32]. 
Table 1. Categorization of the national environmental quality objectives regarding the distribution of causes of the underlying environmental issue (global, continental, national) and type of objective (mainly pollution-related or land-userelated).

\begin{tabular}{|c|c|c|}
\hline \multirow{2}{*}{$\begin{array}{l}\text { Main Distribution of Causes to the } \\
\text { Environmental Issues Addressed by } \\
\text { the Environmental Quality Objectives }\end{array}$} & \multicolumn{2}{|c|}{ Environmental Quality Objectives } \\
\hline & Mainly Related to Pollution & Mainly Related to Land Use \\
\hline Global & $\begin{array}{l}\text { 1. Reduced Climate Impact } \\
\text { 4. A Non-Toxic Environment } \\
\text { 5. A Protective Ozone Layer } \\
\text { 6. A Safe Radiation Environment }\end{array}$ & \\
\hline Continental & $\begin{array}{l}\text { 2. Clean Air } \\
\text { 3. Natural Acidification Only } \\
\text { 7. Zero Eutrophication }\end{array}$ & 10. A Balanced Marine Environment \\
\hline National & & $\begin{array}{l}\text { 8. Flourishing Lakes and Streams } \\
\text { 9. Good-Quality Groundwater } \\
\text { 11. Thriving Wetlands } \\
\text { 12. Sustainable Forests } \\
\text { 13. A Varied Agricultural Landscape } \\
\text { 14. A Magnificent Mountain Landscape } \\
\text { 15. A Good Built Environment } \\
\text { 16. A Rich Diversity of Plant and Animal Life }\end{array}$ \\
\hline
\end{tabular}

\section{Methods}

This section describes the approach used to examine the response by companies to the set of Swedish national environmental quality objectives and SDGs [30], including the empirical basis and what information has been used from the studied companies. This study is partly based on a report, originally carried out for the SwEPA, as a contribution from a corporate perspective to the Government's evaluation in 2016 of the state of the environment as it can be interpreted from the national environmental quality objectives [77]. Information regarding the use of SDGs [30] was collected in spring 2020.

\subsection{Selection of Companies}

In total, 50 companies were selected, based on the NACE code [78], to provide as much diversity as possible of different industries. The NACE code is a commonly used statistical classification of economic activities in the European Union (EU). The 88 sectors provided by the NACE code at a two-digit level were aggregated into 13 groups, where each group can be assumed to have similar impacts on the environment. Within each group, one to seven companies were selected among the largest in their line of business (measured as turnover) and thereby leading in terms of economic contribution in Sweden in their sector, respectively. Of the selected companies, 10 percent belong to the SME group (less than 250 employees). These companies have been omitted in this article when it comes to sustainability issues since their reporting habits were not comprehensive enough to evaluate such issues. Collectively, each group contributes to a significant share of environmental impacts in its sector.

The 50 companies had a total of 1.3 million employees, of which 0.25 million (19 percent) belong to the Swedish part of the companies. As an indication of the environmental relevance of the selected companies, their collective share of direct national emissions of carbon dioxide from all sources in Sweden is around 20 percent.

\subsection{Data Collection}

The published objectives and targets adopted by the companies were studied to illustrate whether the integration of environmental consideration has taken place. To map out the structure of the implemented integration, all published environmental objectives 
and targets were grouped into the structure of the 16 national quality objectives. The progress achieved towards each objective and target was checked through the monitoring programs that were linked to a vast majority of objectives and targets. The results achieved were also checked through the prescribed environmental reports, where applicable.

All the selected companies had publicly made data available on adopted environmental objectives, targets and achieved environmental performance. In most cases (86 percent), data were collected from their latest public sustainability reports. For the remaining 14 percent of companies, data were collected from other public sources, such as information available on their websites, EMAS reports [79] or environmental reports submitted to a public authority (site-specific compliance reports), respectively.

For the first survey in 2015, the latest available sustainability report was used, leading to activities in 2013 or, in a few cases, a few years earlier. The study in 2020 covered activities in 2018 and 2019. Thirty-eight companies in this survey (mainly within NACE 1-39) need to submit an environmental compliance report annually to the authorities. This is a requirement for large sites under the national interpretation of the IED directive [80] in the EU. These reports were used to double-check the information given in other sources, and in a few cases, were the main source of information for a company. Further, most of the sustainability reports and EMAS reports [79] have been audited by an accredited accountant or specialized accountant.

A few interviews were also carried out as part of the first study, mainly to doublecheck the information given in written sources. In total, 16 environmental experts from 6 of the companies were selected based on a set of pre-defined questions, primarily to capture their views on the role of the set of national environmental quality objectives, as seen from a company's point of view. They were selected among the forestry, mining, iron and steel, pulp and paper and motor vehicle sectors. The interviews dealt with the role of the national environmental quality objectives at the company level and driving forces and barriers to environmental improvements. The interviews were conducted individually, face-to-face, and in a few cases, by telephone. All the companies concerned have been given the opportunity to review notes covering the empirical basis for their company.

The annual reports or sustainability reports were studied to capture information on whether a company had initiated any steps to support any of the SDGs [30]. Any link to a specific goal was noted.

\section{Results}

The results are presented following the previously mentioned purposes of the set of environmental quality objectives. The first and most elaborated task of this study was to examine whether the integration of environmental consideration has taken place and-if so- - what role the national environmental quality objectives play (Section 4.1). A second task responds to the third purpose of the national environmental quality objectives (see Section 3), namely, to enhance the knowledge of environmental issues (Section 4.2). A short overview of commitments to the SDG is also given to assess whether the SDGs actually have been endorsed by the studied group of companies and, consequently, if it is meaningful to identify lessons to be learnt (Section 4.3).

\subsection{Integrate Environmental Considerations in All Sectors}

Integration of environmental considerations into all sectors in Sweden has been going on for many years and has interacted with several other factors to trigger improvement, as previously mentioned. This observation is acknowledged in the bill to the national environmental quality objectives since the government claims that legislation is not the entire answer to achieving the objectives and targets.

Some of the companies' state that the national environmental objectives are too vague and have a political character to play any clear role as a model for their own efforts to improve their environmental management, other than their role to indicate key areas of importance. 
The following review illustrates the type of objectives and targets that have been adopted by the companies and how they can be linked to the set of national environmental quality objectives. Table 2 gives an overview of the established environmental objectives and targets by companies. Objectives and targets could be found within the area of 9 of the 16 national environmental quality objectives. For example, 90 percent of the selected companies have established their own objectives, targets and action programs to tackle their contribution to the climate change issue. Similarly, 48 percent of the companies have established objectives and targets linked to the built environment.

Table 2. Overview of established environmental objectives for companies in this study.

\begin{tabular}{|c|c|c|c|c|}
\hline \multirow[t]{2}{*}{ Environmental Issues } & \multicolumn{3}{|c|}{ Number of Companies That Have Established Environmental Objectives } & \multirow[b]{2}{*}{$\begin{array}{l}\text { Share of All } \\
\text { Companies } \\
\text { (NACE 1-99) } \\
\text { (Percent) }\end{array}$} \\
\hline & $\begin{array}{l}\text { Companies Based on the } \\
\text { Use of Natural Resources } \\
\text { (NACE 1-9) }\end{array}$ & $\begin{array}{l}\text { Manufacturing Companies } \\
\text { and Energy Supply } \\
\text { (NACE 10-35) }\end{array}$ & $\begin{array}{l}\text { Other Types } \\
\text { of Companies } \\
\text { (NACE 36-99) }\end{array}$ & \\
\hline Climate change (Objective 1 ) & 3 & 31 & 11 & 90 \\
\hline Air pollution (Objective 2) & 1 & 3 & 2 & 12 \\
\hline Acidification (Objective 3) & 2 & 2 & 0 & 8 \\
\hline $\begin{array}{l}\text { The use of chemical products } \\
\text { with undesirable features } \\
\text { (Objective } 4 \text { ) }\end{array}$ & 1 & 3 & 4 & 16 \\
\hline $\begin{array}{l}\text { A protective ozone layer } \\
\text { (Objective 5) }\end{array}$ & 0 & 2 & 0 & 4 \\
\hline Eutrophication (Objective 7) & 1 & 5 & 0 & 12 \\
\hline $\begin{array}{l}\text { Productive forestry and } \\
\text { Preserved biodiversity } \\
\text { (Objective 12) }\end{array}$ & 1 & 4 & 0 & 10 \\
\hline $\begin{array}{l}\text { Productive agriculture and } \\
\text { preserved agriculture } \\
\text { (Objective 13) }\end{array}$ & 1 & 1 & 0 & 4 \\
\hline $\begin{array}{c}\text { Environmental issues linked to } \\
\text { the built environment } \\
\text { (Objective 15) }\end{array}$ & 1 & 14 & 19 & 48 \\
\hline Included companies & 3 & 32 & 13 & 100 \\
\hline
\end{tabular}

An overview of the established site-specific legal requirements is given in Table 3. It should be noted that the legal requirements are generally targeted to individual sites (factories, etc.) in Sweden, while the reported environmental objectives (Table 2) are established company-wide, implying that they also cover activities outside of Sweden, to some extent also including activities by suppliers. It should also be noted that the legal requirements for emissions of greenhouse gases (GHGs) are linked to the emissions trade system (EU ETS) in the EU [12] and are not visible in Table 3.

Seven of the national environmental quality objectives deal with pollution. As noted above, climate change issues (Objective 1, Reduced Climate Impact) have engaged all the reviewed companies most. An overwhelming share of the 50 companies (90 percent) has adopted and made public their own objectives for the years to come. The targets are either worded as a reduction of greenhouse gases (GHGs) or the use of energy, or both. The concerned companies have developed long-term roadmaps focusing on creating low-carbon processes, such as those producing steel and cement. Several companies in the transport sector promote the improvement of fuel efficiency and seek alternatives with less carbon emissions. Many companies are testing new types of vehicles, fuels and other methods. Energy efficiency is a top priority issue in most companies. Companies in the 
forestry and pulp and paper sectors reduce conflicts as much as possible, in part through consultations with those concerned. Many companies cited environmental issues in urban areas (Objective 15, A Good Built Environment), mainly as a management issue. This objective includes a diverse series of issues. The efficient use of materials is mentioned, such as the use of waste rock from mines to produce ballast for the construction industry in the region and replacing gravel in concrete production. Reuse and recycling of metals is another issue. A wide range of materials is recycled, such as construction waste, food, fiber, garment, e-waste and metals. Other industries have also developed their procedures for proper waste management. The biodiversity issue (Objective 16, A Rich Diversity of Plant and Animal Life) is expressed by companies in the raw material sector (NACE 1-5, 20-21, 26), where, in a few cases, far- reaching commitments have been made. Many companies make company commitments to conserve biodiversity.

Table 3. Overview of established site-specific legal environmental requirements for companies in this study.

\begin{tabular}{|c|c|c|c|c|}
\hline \multirow[t]{2}{*}{ Environmental Issues } & \multicolumn{4}{|c|}{$\begin{array}{c}\text { Number of Companies That Must Comply with Governmental Environmental Legal } \\
\text { Requirements for Major Sites }\end{array}$} \\
\hline & $\begin{array}{l}\text { Companies Based on the } \\
\text { Use of Natural Resources } \\
\text { (NACE 1-9) }\end{array}$ & $\begin{array}{l}\text { Manufacturing Companies } \\
\text { and Energy Supply } \\
\text { (NACE 10-35) }\end{array}$ & $\begin{array}{l}\text { Other Types } \\
\text { of Companies } \\
\text { (NACE 36-99) }\end{array}$ & $\begin{array}{l}\text { Share of all } \\
\text { Companies } \\
\text { (NACE 1-99) } \\
\text { (Percent) }\end{array}$ \\
\hline Climate change (Objective 1) & NA & NA & NA & NA \\
\hline Air pollution (Objective 2) & 3 & 28 & 2 & 66 \\
\hline Acidification (Objective 3) & 2 & 16 & 1 & 38 \\
\hline $\begin{array}{l}\text { The use of chemical products } \\
\text { with undesirable features } \\
\text { (Objective } 4)\end{array}$ & 3 & 28 & 1 & 64 \\
\hline $\begin{array}{l}\text { A protective ozone layer } \\
\text { (Objective 5) }\end{array}$ & 0 & 2 & 0 & 4 \\
\hline Eutrophication (Objective 7) & 4 & 24 & 1 & 58 \\
\hline $\begin{array}{l}\text { Productive forestry and } \\
\text { preserved biodiversity } \\
\text { (Objective 12) }\end{array}$ & 1 & 4 & 0 & 10 \\
\hline $\begin{array}{c}\text { Productive agriculture and } \\
\text { preserved biodiversity } \\
\text { (Objective 13) }\end{array}$ & 0 & 0 & 0 & 0 \\
\hline $\begin{array}{c}\text { Environmental issues linked to } \\
\text { the built environment } \\
\text { (Objective 15) }\end{array}$ & 4 & 29 & 2 & 70 \\
\hline Included companies & 5 & 32 & 13 & 100 \\
\hline
\end{tabular}

Note: Legal requirements for emissions of GHGs are linked to the emissions trade system in the EU (EU ETS) and are not visible in this table [12].

The internal process to reduce environmental impacts of a company is actually a mix of dealing with regulated environmental issues at individual sites as target and environmental issues that are managed by using objectives and targets for the entire company, including operations beyond the national borders. According to this study, already regulated environmental issues such as REACH [81] are only exceptionally subject to internal objectives and targets within the companies, whereas such internal processes are mainly used for non-regulated environmental issues, such as the climate change issue, which in the EU is subject to a trading system (EU ETS) for the large sources [12]. Almost all companies in this study have established objectives and targets to decrease the impact on the climate. The share for other environmental objectives is lower, because companies in this study have to take into account both their own environmental objectives and the requirements 
established by law for their sites operating in Sweden. Nilsson [82] discusses this issue and claims that ownership and accountability of sustainability issues must land firmly within the sectors. It should be noted that voluntary systems play an important role in dealing with non-legislated issues. The contribution of companies to SDGs can be estimated by the high use of other sustainability tools of companies in this study, such as the UN Global Compact and GRI $[16,18,19]$.

One observation made during the study of sustainability reports of the group of companies in this study was the absence of reference to the set of national environmental quality objectives. When it comes to the integration of environmental concerns in all sectors, the interviewees provide additional insights. It becomes clear that national policies, like the national environmental objectives, are well known. However, they seem to play a limited role in the multinational companies which dominate this study. An overwhelming share of companies declare as an ambition that legal requirements shall not only be complied with but also exceeded. At the same time, an environmental expert at one of the companies explicitly says in an interview that they avoid national systems, which is beyond what is legally required.

To identify lessons to be learnt for the SDGs, it could be noted that both systems are based on goals but lack a specific mechanism for implementation. However, the overwhelming majority of companies in this study have since long established an implementation mechanism for their own objectives and targets. The overwhelming share of companies have implemented their own objective-related systems to tackle environmental issues in terms of an environmental management system, based on the international environmental management standard ISO 14001 [15]. In this study, 86 percent of the companies have voluntarily implemented an environmental management system based on international standards. Such systems include procedures to identify their significant environmental aspects, which play a role as the basis in establishing tailor-made objectives and targets for the company in question.

\subsection{Enhance Knowledge of Environmental Issues}

According to the interviews, most of the selected companies are aware of the national environmental quality objectives. They are used, for example, in connection with environmental permitting procedures. Companies suggest that the environmental quality objectives may be relevant in the sense that they indicate the key environmental areas from a governmental perspective when targets are established within companies. However, according to them, some of the national objectives are difficult to manage at a company level, as they have a visionary and national political character.

\subsection{Enhance Knowledge on Sustainability Issue and Integration into Daily Operations}

The knowledge of the SDGs [30] seems to have increased; only 1-2 years after they were published, more than 90 percent of the large companies had not only endorsed them but also indicated which of the 17 goals are relevant for their businesses and in detail described what kind of support they can provide (Table 4). The SDG goals that seem to affect most companies are No. 12 and 13. 
Table 4. Commitments to the UN 2030 goal among large companies in Sweden 2018/19.

\section{Sustainability Goal (UN SDG)}

Share (Percent) of Companies That Explicitly Have Committed Themselves to Support the Achievement of the UN SDG Goals

Natural
Resources

Manufacturing and Energy Supply (NACE 10-35)

Other (NACE 36-99)
All Companies (NACE 1-99)

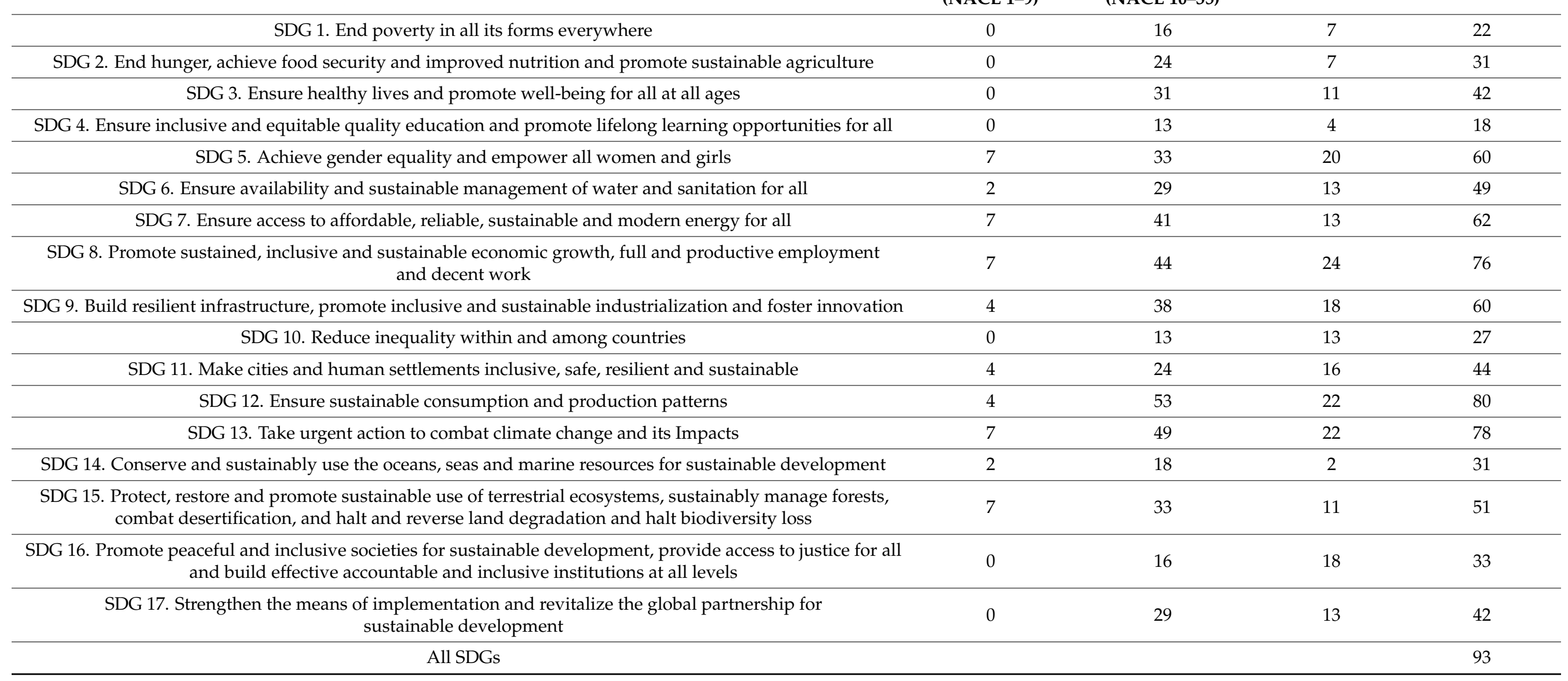

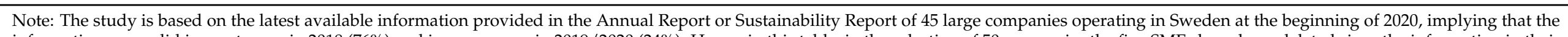

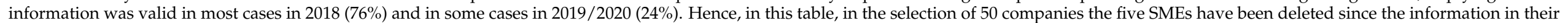
reports does not allow any evaluation of relationship to the UN SDGs. 


\section{Discussion}

The following discussion relates to the previously mentioned key features of the set of general objectives (be clear, be suitable to the business agenda, include an implementation mechanism, be possible to evaluate, be timed and known to the target group), how these issues are dealt with by companies and which lessons can be learnt for the implementation of the SDGs in the business sector.

Implementation problems linked to a lack of clarity are confirmed by many studies $[56,68-71,74,83]$. For obvious reasons, the SDGs are also vaguely phrased and can, therefore, be subject to similar interpretation problems as the national quality objectives. In fact, most of them rather look like metaphors. On the other hand, companies seem to be able to establish local targets for their own activities, based on these metaphors.

A set of general goals needs to fit into the companies' agenda to be suitable. Both sets of goals have the character of formalization of long-term phenomena, established long ago. The issues covered by the environmental quality objectives have been systematically implemented for several decades. The issues covered by the SDGs [30] have been systematically implemented by the big companies through GRI [16] and the UN Global Compact [18] for at least a decade. The reporting via GRI [16] implies that companies, in broad terms, have dealt with the same issues for many years that are covered by the SDGs [30]. Different behavior changes that could contribute to achieving a set of sustainability objectives are discussed by van Vuuren et al. [84].

The meaning of the term suitable has been discussed. Stakeholders advocate that the set of objectives, rather, should be seen as a tool to guide and inspire [73] and-the original idea-to bridge the communication gap between experts and citizens, according to Rubenson [71], quoting former state secretary Måns Lönnroth. The reason for the latter approach was that environmental policy differs from other policy areas in that it is based on scientific concepts, not citizens' everyday lives. Moreover, the environmental quality objectives should be seen as purely political objectives and a kind of point for orientation in time, space and themes, rather than as a basis for management by objectives, which, according to Lönnroth [72], is not a very suitable form of governing. When the issue is politically solved, the case would be considered fulfilled. One can also consider the national environmental quality objectives as a kind of codification of the issues that were on the environmental agenda when this set of objectives was created [72]. In the latter case, different follow-up procedures play a minor role.

The question of whether the environmental quality objectives have really contributed to improving environmental performance has been discussed by many stakeholders. Wandén [85] elaborates on the fact that there are numerous goal conflicts to consider. OECD comments in its evaluation of the Swedish environmental policy, saying that while the overall environmental quality is very good, the country faces challenges in meeting the very ambitious environmental quality objectives it has set for itself [25]. Dalhammar [86] states, for example, that it is debatable if-and in that case to what level-the objectives will contribute to the improved environmental performance of companies. Others comment similarly $[44,71]$. Several sources claim that the level of ambition is unrealistically high, and only a few of the objectives will be achieved on time $[2,56,59,60,63,71]$. To continue, Wibeck et al. [74] comment that there is room for considerable interpretation-and misinterpretation - of what measures to take and in what order, and of how these measures should be evaluated. Lundgren [70] and Rubenson [71] make similar comments and state that many interesting fights over interpretation can be foreseen since the objectives and targets, in general, are phrased in very general terms. Arnfalk et al. [68] also raise some doubts; according to these authors, it has been expected that the business community would take action to reduce environmental aspects based on the national environmental objectives. Such actions have certainly been taken, but, according to Arnfalk et al. [68], are hardly based on these objectives, but rather on environmental management systems and other similar voluntary tools. All the mentioned predictions have come true, since only a 
few objectives are considered achieved. The final evaluation of the national environmental quality objectives was not published at the time when this article was finalized.

The study indicates that integration of environmental considerations takes place, and in many cases, beyond the spirit of the national environmental quality objectives. Studying objectives and targets published by the selection of companies indicates that they are addressing the same issues as the national environmental quality objectives. It seems reasonable to explain this similarity by the scope of the set of objectives, which mainly coincide with the environmental agenda at the time they were made [72]. In fact, the compilation of environmental issues can be traced back to the early 1980s [87]. The SDGs are also a compilation of well-established issues, which have long been dealt with in Swedish companies with the support of other sustainability tools, such as the UN Global Compact [18,19], ISO 26000 [36] and GRI, the Global Reporting Initiative [16].

It should be pointed out, according to Dalhammar [2] and Rubenson [71], that there are no specific implementation mechanisms included in the set of environmental quality objectives which is confirmed by the government's statement that all available instruments shall be used [27]. Thus, the results reflect all kinds of influences for improvement, not only by these objectives $[2,56,71,73]$. One challenge is tied to the difficulty of knowing what set of indicators will be broad enough on which to base the assessment [88]. Furthermore, the sustainability issue has been embraced by at least the large and medium-sized companies in Sweden, given the high level of commitment to such systems by companies in this study. It must be stated, though, that many of these companies probably are far from compatible with all the issues mentioned in the present set of sustainability issues in the SDGs [30].

In reality, the implementation mechanism for establishing objectives, targets and improvement programs at the company level seems to be the environmental management system (EMS), which has been implemented in accordance with the international environmental management standard ISO 14001 [15], independently of which governmental policy instrument has initiated action in the first place. The commitments to the SDGs [30] can easily be included in such systems.

By studying the environmental quality objectives and their role in implementing improved environmental performance, there is a split view among the concerned stakeholders. Stakeholders advocate that the objectives should clearly define what the government wants to achieve. In this case, objectives, time frames and follow-up procedures play an important role in strategic and tactical considerations [73]. A proponent of this approach was the Swedish National Audit Office [76], which serves directly under the Parliament. The regular evaluations by the Environmental Objectives Council [46-55] and the SwEPA [57-67], as previously mentioned, on the progress of the implementation, have adopted this approach. Others argue that they can be considered as a summary of the government's environmental policy and the environmental results-the state of the environment- to be achieved within the perspective of one generation [2,71].

It can be noted that the set of national objectives does not comply with criteria that are normally applicable for management by objectives [74]. As previously mentioned, management by objectives is not a very suitable way of governing at the national or supra-national level [72]. Linnér and Wibeck [89] explain the circumstances under which transformation can be governed.

The evaluation procedure needs to be carefully designed. According to Larsson and Hanberger [83], it is unlikely that the current evaluation function can effectively support the achievement of the national environmental objectives. In the case of the pollution-related national environmental quality objectives, there is an annoying mismatch. On the one side, there is the scope of the environmental quality objectives, which are mainly formulated at the continental or global level. On the other side, there is the action initiated at the national level, implying that improved environmental quality reflects countermeasures implemented on the European continent or globally, where the share of national pollution and linked countermeasures is about 10 percent (1-40 percent, depending on the measured indicator). National governments can only govern activities within a nation. Indirectly, 
a national government can govern other countries via the EU environmental acquis and international conventions. None of the pollution-related environmental quality objectives, to express it bluntly, would be possible to achieve, even if all activities in Sweden totally ceased, unless sources beyond national borders decrease their emissions likewise. Therefore, it is reasonable to suggest that the main reason that the national environmental quality objectives have not been achieved is the mentioned mismatch. A similar complication can affect the SDGs [30] if not appropriately evaluated.

Both visions of a future state of the environment and sustainability are timed long-term, 15-20 years. The Swedish environmental quality objectives are expected to be met by 2020, but this has not been the case other than for a few objectives. The SDGs are expected to be met by 2030. The transformation of our global society to sustainability is obviously a huge undertaking and will probably not be finalized within 15 years, especially since there is probably no final destination.

No set of general objectives will be achieved if they are not known by the target group $[72,74,75]$. Since all the selected companies have implemented environmental programs that include objectives, targets and action programs that are relevant to their businesses, none of these can be considered ignorant of environmental issues. The sources of information for designing environmental programs are manifold, including information from stakeholders, such as customers and owners, authorities and the national environmental objectives as guides for key environmental areas. In this case, both sets of objectives are known to the target group. More than 90 percent of the companies had committed themselves to the SDGs only 1-2 years after publication. Similar commitments hardly exist for the national environmental quality objectives, even 20 years after their establishment.

\section{Conclusions}

This article examines the implementation of the Swedish national environmental quality objectives and discusses what can be learnt for the equivalent process for the SDGs. We show that the most important purpose of the set of Swedish national environmental quality objectives, as seen from a corporate perspective, that is, to integrate environmental concerns in all sectors, seems to be well in line with actions taken by industry and also to be well known.

However, the established SDGs are crafted with a broader approach than the Swedish set of environmental quality objectives. The SDGs probably better reflect the agenda of the business community since they have a global character, cover the whole spectrum of important sustainability issues and provide a mutual agenda for the business community worldwide. It seems as if some major shortcomings of the SDGs can be overcome, based on the initial application at the company level, such as they all suffer from similar deficit implementation mechanisms as the Swedish environmental quality objectives. Further, action plans have been addressed only via the UN member states and are purely politically phrased, the track to sustainable development is only vaguely expressed and the distance to the actors is large to those who are supposed to make a reality of the 17 identified areas. Evaluations of visions should be made with the perspective in which they are formulated. One example is the set of national environmental quality objectives, which is evaluated as if pollutants only have national distribution, even though most of the impact on Swedish environmental quality comes from nearby countries and in a few cases from countries all over the world.

It seems reasonable to suggest that the SDGs can substantially contribute to the track of sustainable development in industry, in addition to the already established tools with similar purposes, such as the UN Global Compact, ISO 26000:2010 on social responsibility and the Global Reporting Initiative (GRI) on reporting habits. The practical policy implication is that policy-makers and practitioners have got a new additional and clearer framework that clarifies and enriches the meaning of the concept of sustainable development.

Author Contributions: Conceptualization, R.A. and O.H.; methodology, R.A.; software, R.A.; validation, R.A.; formal analysis, R.A.; Investigation, R.A.; resources, R.A.; data curation, R.A.; writing- 
original draft preparation, R.A.; writing-review and editing, R.A.; visualization, R.A.; supervision, O.H.; project administration, R.A.; funding acquisition, R.A. All authors have read and agreed to the published version of the manuscript.

Funding: This research received no external funding.

Institutional Review Board Statement: Not applicable.

Informed Consent Statement: Not applicable.

Data Availability Statement: Publicly available datasets were analyzed in this study. This data can be found using the links provided within the article or on request from the corresponding author.

Conflicts of Interest: The authors declare no conflict of interest.

\section{References}

1. Cole, M.; Elliot, R.; Shimamoto, K. Industrial Characteristics, Environmental Regulations and Air Pollution: An Analysis of the UK Manufacturing Sector. J. Environ. Econ. Manag. 2005, 50, 121-143. [CrossRef]

2. Jaffe, A.B.; Newell, R.; Stavins, R.N. A Tale of Two Market Failures: Technology and Environmental Policy. Ecol. Econ. 2005, 54, 164-174. Available online: ideas.repec.org/p/ags/rffdps/10815.html (accessed on 17 May 2021). [CrossRef]

3. Dalhammar, C. The Environmental Quality Objectives and the Environmental Code-Opportunities for Enforcing Environmental Quality Objectives; Report 2008:1; The International Institute for Industrial Environmental Economics (IIIEE): Lund, Sweden, 2008; Available online: lup.lub.lu.se/record/1152332 (accessed on 17 May 2021).

4. OECD. An OECD Framework for Effective and Efficient Environmental Policies: Overview; ENV/EPOC(2008)6/FINAL; OECD: Paris, France, 2008.

5. Bergek, A.; Berggren, C. The Impact of Environmental Policy Instruments on Innovation: A Review of Energy and Automotive Industry Studies. Ecol. Econ. 2014, 106, 112-123. [CrossRef]

6. Demirel, P.; Kesidou, E. Stimulating Different Types of Eco-Innovation in the UK: Government Policies and Firm Motivations. In Ecological Economics; Elsevier: Amsterdam, The Netherlands, 2011; Volume 70, pp. 1546-1557. Available online: ideas.repec.org/ $\mathrm{p} / \mathrm{met} / \mathrm{stpswp} / 1203 . \mathrm{html}$ (accessed on 17 May 2021).

7. Kemp, R.; Pontoglio, S. The Innovation Effects of Environmental Policy Instruments-A Typical Case of the Blind Men and the Elephant. Ecol. Econ. 2011, 72, 28-36. [CrossRef]

8. Krysiak, F. Environmental Regulation, Technological Diversity, and the Dynamics of Technological Change. J. Econ. Dyn. Control 2011, 35, 528-544. [CrossRef]

9. Lanoie, P.; Laurent-Lucchetti, J.; Johnstone, N.; Ambec, S. Environmental Policy, Innovation and Performance: New Insights on the Porter Hypothesis. J. Econ. Manag. Strateg. 2011, 20, 803-842. Available online: hal.inrae.fr/hal-02823256 (accessed on 17 May 2021). [CrossRef]

10. Pettersson, M.; Söderholm, P. Industrial Pollution Control and Efficient Licensing Processes: The Case of Swedish Regulatory Design. Sustainability 2014, 6, 5401-5422. [CrossRef]

11. Popp, D. Innovation and Climate Policy. NBER Working Paper No. 15673. 2010. Available online: ideas.repec.org/p/nbr/ nberwo/15673.html (accessed on 17 May 2021).

12. European Parliament and the Council. EU ETS, Directive 87/2003/EC on Greenhouse Gas Emission Allowances Trading within the Community. 2003. Available online: https://eur-lex.europa.eu/legal-content/EN/TXT/PDF/?uri=CELEX:32003L0087\& from $=\mathrm{EN}$ (accessed on 17 May 2021).

13. Almgren, R. A Toolbox for Greening of Products; Swedish Enterprise: Styockholm, Sweden, 2002.

14. Brorson, T. 2019. Available online: https:/ / www.Advantage-Environment.com (accessed on 17 May 2021).

15. ISO. ISO 14000 Family_Environmental Management; ISO: Geneva, Switzerland, 2020; Available online: https:/ /www.iso.org/iso14001-environmental-management.html (accessed on 17 May 2021).

16. Global Reporting Initiative, GRI. Sustainability Reporting Guidelines. 2018. Available online: globalreporting.org (accessed on 17 May 2021).

17. UN. Sustainable Development. Agenda 21. United Nations Conference on Environment and Development. 1992. Available online: https:/ / sustainabledevelopment.un.org/content/documents/Agenda21.pdf (accessed on 17 May 2021).

18. UN. Global Compact. Ten Principles. 2018. Available online: https://www.unglobalcompact.org (accessed on 17 May 2021).

19. UN. United Nations Global Compact Progress Report. Business Solutions to Sustainable Development. 2017. Available online: https:/ / d306pr3pise04h.cloudfront.net/docs/publications\%2FUN+Impact+Brochure_Concept-FINAL.pdf (accessed on 17 May 2021).

20. UN. Millennium Development Goals (MDGs). 2000. Available online: https:/ /www.un.org (accessed on 17 May 2021).

21. Paleari, S.; Reichel, A. EU Environmental Targets and Objectives 2015-2050. In European Environment Agency, Eionet ReportETC/WMGE 2019/2. Available online: zenodo.org/record/3778419 (accessed on 17 May 2021).

22. CLRTAP. Strategies and Policies for Air Pollution Abatement. 2013. Available online: https://www.eea.europa.eu/ (accessed on 17 May 2021). 
23. HELCOM. Baltic Sea Action Plan. 2007. Available online: https://helcom.fi/media/documents/BSAP_Final.pdf (accessed on 17 May 2021).

24. OSPAR Commission. Annual Report 2012/13. Available online: https:/ / www.ospar.org/documents?v=7344 (accessed on 17 May 2021).

25. OECD. Environmental Performance Reviews: Sweden. 2014. Available online: https://www.oecd.org/env/country-reviews/ oecd-environmental-performance-reviews-sweden-2014-9789264213715-en.htm (accessed on 17 May 2021).

26. Swedish Government. Government Bill 1997/98:145, Swedish Environmental Objective; Swedish Government: Stockholm, Sweden, 1998.

27. Swedish Government. Government Bill 2000/01:130, The Swedish Environmental Quality Objectives: Interim Targets and Action Strategies; Swedish Government: Stockholm, Sweden, 2001.

28. Swedish Government. Government Bill 2001/02:55, Sweden's Climate Strategy; Swedish Government: Stockholm, Sweden, 2001.

29. Swedish Government. Government Bill 2004/05:150, Swedish Environmental Objectives—A Shared Responsibility; Swedish Government: Stockholm, Sweden, 2005.

30. UN. Transforming Our World: The 2030 Agenda for Sustainable Development; Resolution Adopted by the UN General Assembly on 25 September 2015 (A/Res/70/1); UN: New York, NY, USA, 2015.

31. Hajer, M.; Nilsson, M.; Raworth, P.; Berkhout, F.; de Boer, Y.; Rockström, J.; Ludwig, K.; Kok, M. Beyond cockpitism: Four Insights to Enhance the Transformative Potential of the Sustainable Development Goals. Sustainability 2015, 7, 1651-1660. [CrossRef]

32. Denoncourt, J. Companies and UN 2030 Sustainable Development Goal 9 Industry, Innovation and Infrastructure. J. Corp. Law Stud. 2020, 20, 199-235. [CrossRef]

33. Eliasson, K.; Wibeck, V.; Neset, T. Opportunities and Challenges for Meeting the UN 2030 Agenda in the Light of Global Change-A Case Study of Swedish Perspectives. Sustanability 2019, 11, 5221. [CrossRef]

34. WCED, World Commission on Environment and Development. Our Common Future; Oxford University Press: Oxford, UK, 1987.

35. European Parliament and the Council. A General Union Environment Action Program to 2030, "Living well within the limits of our planet". Decision No 1386/2013/EU. Available online: https:/ / www.europa.eu (accessed on 17 May 2021).

36. ISO. ISO 26000:2010. Guidelines on Social Responsibility. 2010. Available online: https://www.iso.org/standard/42546.html (accessed on 17 May 2021).

37. Naturvårdsverket. SwEPA, Clean Air and Green Forests; Report 4765; Naturvårdsverket: Stockholm, Sweden, 1997.

38. Swedish Government. Government Bill 2008/09:162, a Coherent Climate and Energy Policy; Swedish Government: Stockholm, Sweden, 2008.

39. Swedish Government. Government Bill 2009/10:155, Swedish Environmental Objectives—To Make Environmental Activities More Efficient; Swedish Government: Stockholm, Sweden, 2009.

40. Swedish Government. Swedish Government Bill 2013/14:39, on the Way to a Non-Toxic Everyday Life-Platform for a Chemicals Policy; Swedish Government: Stockholm, Sweden, 2013.

41. Swedish Government. Government Bill 2013/14:141, a Swedish Strategy for Biodiversity and Ecosystem Services; Swedish Government: Stockholm, Sweden, 2013.

42. Swedish Government. Government Communication 2013/14:145, Swedish Environmental Objectives Indicate the Way Forward; Swedish Government: Stockholm, Sweden, 2013.

43. Swedish Parliament. Decision MJU 1998/99:6, skr 1998/99:183; Swedish Parliament: Stockholm, Sweden, 1998.

44. Emmelin, L. The Environmental Quality Objectives-A Technocratic Utopia. In Generationsmålet-Tankar om Miljöpolitik och Samhällsomställning; Lundgren, L.J., Schough, K., Eds.; Naturvårdsverket: Stockholm, Sweden, 2014; pp. 51-76.

45. Emmelin, L.; Cherp, A. National Environmental Objectives in Sweden-A Critical Reflection. J. Clean. Prod. 2016, 123, 194-199. [CrossRef]

46. The National Environment Quality Council. The Environmental Objectives—Will We Reach Them? de Facto; The National Environment Quality Council: Stockholm, Sweden, 2002; ISBN 91-620-1225-8.

47. The National Environment Quality Council. The Environmental Quality Objectives_Will We Reach Them? de Facto; The National Environment Quality Council: Stockholm, Sweden, 2003; ISBN 91-620-1231-2.

48. The National Environment Quality Council. The Environmental Quality Objectives-A Shared Responsibility; The National Environment Quality Council: Stockholm, Sweden, 2004; ISBN 91-620-628-1235-5.

49. The National Environment Quality Council. The Environmental Quality Objectives—Will We Reach Them; de Facto; The National Environment Quality Council: Stockholm, Sweden, 2004; ISBN 91-620-1237-1.

50. The National Environment Quality Council. The Environmental Quality Objectives—For the Sake of Our Children; de Facto; The National Environment Quality Council: Stockholm, Sweden, 2005; ISBN 91-620-1240-1.

51. The National Environment Quality Council. The Environmental Objectives into the Bargain; de Facto; The National Environment Quality Council: Stockholm, Sweden, 2006; ISBN 91-620-1250-9.

52. The National Environment Quality Council. The Environmental Quality Objectives—In an International Perspective; de Facto; The National Environment Quality Council: Stockholm, Sweden, 2007; ISBN 91-620-1259-2.

53. The National Environment Quality Council. The Environmental Quality Objectives—No Time to Lose; The National Environment Quality Council: Stockholm, Sweden, 2008; ISBN 978-91-620-1264-9. 
54. The National Environment Quality Council. The Environmental Quality Objectives-At Half Time; de Facto; The National Environment Quality Council: Stockholm, Sweden, 2009; ISBN 978-91-620-1272-4.

55. The National Environment Quality Council. The Environmental Quality Objectives-Swedish Consumption and Global Environmental Impact; de Facto; The National Environment Quality Council: Stockholm, Sweden, 2010.

56. SOU 2009:83. Miljömålen i nya perspektiv [The Environmental Objectives in a New Perspective. The Government's Official investigations] Utredningen om Miljömålssystemet; Sveriges Offentliga Utredningar: Stockholm, Sweden, 2009.

57. Naturvårdsverket. SwEPA, Further Steps-In-Depth Review of the Swedish Environmental Quality Objectives; Report 6500; Naturvårdsverket: Stockholm, Sweden, 2012; ISBN 978-91-620-6520-3.

58. Naturvårdsverket. SwEPA, Review of the Generation Objective; Report 6504; Naturvårdsverket: Stockholm, Sweden, 2012; ISBN 978-91-620-6504-1.

59. Naturvårdsverket. SwEPA, The Environmental Quality Objectives-Annual Review of Sweden's Environmental Quality Objectives and Interim Targets 2013; Report 6557; Naturvårdsverket: Stockholm, Sweden, 2013; ISBN 978-92-620-6557-7.

60. Naturvårdsverket. Miljömålen. Årlig Uppföljning av Sveriges Miljökvalitetsmål och Etappmål 2014 SwEPA The Environmental Quality Objectives-Annual Review of Sweden's Environmental Quality Objectives and Interim Targets 2014; Report 6608; Naturvårdsverket: Stockholm, Sweden, 2014; ISBN 978-91-620-6608-6.

61. Naturvårdsverket. Miljömålen. Årlig Uppföljning av Sveriges Miljökvalitetsmål och Etappmål. [SwEPA, The Environmental Quality Objectives-Annual Review of Sweden's Environmental Quality Objectives and Interim Targets]; Report 6661; Naturvårdsverket: Stockholm, Sweden, 2015; ISBN 978-91-620-6661-1.

62. Naturvårdsverket. Målövergripande Analys av Miljömålen. [SwEPA, In-Depth Analyses of the Environmental Quality Objectives]; Report 6692; Naturvårdsverket: Stockholm, Sweden, 2015; ISBN 978-91-620-6692-5.

63. Naturvårdsverket. Miljömålen. Årlig Uppföljning av Sveriges Miljökvalitetsmål och Etappmål 2016. [SwEPA, The Environmental Quality Objectives-Annual Review of Sweden's Environmental Quality Objectives and Interim Targets]; Report 6707; Naturvårdsverket: Stockholm, Sweden, 2016; ISBN 978-91-620-6707-6.

64. Naturvårdsverket. Miljömålen Årlig Uppföljning av Sveriges Nationella Miljömål 2017 [SwEPA, The Environmental Quality ObjectivesAnnual Review of Sweden's Environmental Quality Objectives and Interim Targets 2017]; Report 6749; Naturvårdsverket: Stockholm, Sweden, 2017; ISBN 978-91-620-6749-6.

65. Naturvårdsverket. Miljömålen Årlig Uppföljning av Sveriges Nationella Miljömål 2018-Med fokus på Statliga Insatser. Reviderad Version maj 2018 [SwEPA, The Environmental Quality Objectives-Annual Review of Sweden's Environmental Quality Objectives and Interim Targets-Focus on Governmental Efforts]; Report 6833; Naturvårdsverket: Stockholm, Sweden, 2018; ISBN 978-91-620-6833-2.

66. Naturvårdsverket. Fördjupad Utvärdering av Miljömålen 2019. Med förslag till Regeringen från Myndigheter i Samverkan [SwEPA, The Environmental Quality Objectives-In-Depth Review of Sweden's Environmental Quality Objectives. Proposals from the Involved Governmental Bodies]; Report 6919; Naturvårdsverket: Stockholm, Sweden, 2019; ISBN 98-91-620-6865-3.

67. Naturvårdsverket. Miljömålen Årlig Uppföljning av Sveriges Nationella Miljömål 2020—Med Fokus på Statliga Insatser [SwEPA, The Environmental Quality Objectives-Annual Review of Sweden's Environmental Quality Objectives-Focus on Governmental Efforts]; Report 6919; Naturvårdsverket: Stockholm, Sweden, 2020; ISBN 978-91-620-6919-3.

68. Arnfalk, P.; Brorson, T.; Thidell. The Environmental Performance of Companies and the Swedish Environmental Quality ObjectivesExperiences and Views Among Sectors of Industry as an Input to the In-Depth Evaluation of the Environmental Quality Objectives; Report; The International Institute for Industrial Environmental Economics (IIIEE): Lund, Sweden, 2008.

69. Edvardsson, K. Using Goals in Environmental Management-The Swedish System of Environmental Objectives. Environ. Manag. 2004, 34, 179-180. Available online: urn.kb.se/resolve?urn=urn:nbn:se:kth:diva-9268 (accessed on 17 May 2021). [CrossRef] [PubMed]

70. Lundgren, L.J. The Environmental Policy_In What the State Wants_Objectives and Ambitions in Swedish Politics; Gidlunds Förlag: Möklinta, Sweden, 2013; pp. 281-346.

71. Rubenson, S. The Formulation of the Environmental Interim Targets as to be Able to Support the Enforcement of the Environmental Code; Report 5964; Tillsyns-och Föreskriftsrådet: Stockholm, Sweden, 2009.

72. Lönnroth, M. How was the generation's objective established? In Generationsmålet_Tankar om Miljöpolitik och Samhällsomställning; Lundgren, L.J., Schough, K., Eds.; Naturvårdsverket: Stockholm, Sweden, 2014; pp. 13-27.

73. Tarschys, D.; Lemne, M. Goal and meaning in Swedish politics. In What the State Wants_Goals and Ambitions in Swedish Politics; Gidlunds Förlag: Möklinta, Sweden, 2013.

74. Wibeck, V.; Johansson, M.; Larsson, A.; Öberg, G. Communicative Aspects of Environmental Management by Objectives: Examples from the Swedish Context. Environ. Manag. 2006, 37, 461-469. [CrossRef] [PubMed]

75. The Swedish National Audit Office. The Environmental Objectives Reporting-Too Much and Too Little; RiR; The Swedish National Audit Office: Stockholm, Sweden, 2005; p. 1.

76. Emmelin, L. Att synas utan att verka-Miljömålen som symbolpolitik [To be visible without effects—Environmental quality objectives as symbolic politics]. In Konflikter, Samarbete, Resultat-Perspektiv på Svensk Miljöpolitik. Festskrift till Valfrid Paulsson; Lundgren, L.J., Edman, J., Eds.; Kassandra: Brottby, Sweden, 2005.

77. Almgren, R. Näringslivets Insatser på Miljöområdet [Environmental Performance of Businesses]. För Naturvårdsverket (SwEPA); Linköping University: Linköping, Sweden, 2015; LIU-IEI-RR-15/00232—SE. 
78. Eurostat. NACE Code. Eurostat: Luxembourg. 2008. Available online: https://ec.europa.eu/eurostat/documents/3859598/5902 521/KS-RA-07-015-EN.PDF (accessed on 17 May 2021).

79. European Parliament and the Council. EMAS, Regulation 1221/2009/EC on Eco-Management and Audit Scheme. Available online: https: / / www.europa.eu (accessed on 17 May 2021).

80. European Parliament and the Council. Industrial Emissions 2010/75/EU. 2010. Available online: https://www.europa.eu (accessed on 17 May 2021).

81. European Parliament and the Council. REACH, Regulation 1907/2006/EC on Registration, Evaluation, Authorization and Restriction of Chemicals. Available online: https:/ / www.europa.eu (accessed on 17 May 2021).

82. Nilsson, M. Connecting Reason to Power-Assessments, Learning and Environmental Policy Integration in Swedish Energy Policy. Stockholm Environment Institute. 2005. Available online: resolver.tudelft.nl.e.bibl.liu.se/uuid:f7338e5a-ab82--49f9--8bdc-93 184b61ac95 (accessed on 17 May 2021).

83. Larsson, M.; Hanberger, A. Evaluation in Management by Objectives: A Critical Analysis of Sweden's National Environmental Quality Objectives System; Umea University: Umea, Sweden, 2016; Available online: urn.kb.se/resolve?urn=urn:nbn:se:umu:diva-119543 (accessed on 17 May 2021).

84. van Vuuren, D.P.; Kok, M.; Lucas, P.L.; Prins, A.G.; Alkemade, R.; van den Berg, M.; Bouwman, L.; van der Esch, S.; Jeuken, M.; Kram, T.; et al. Pathways to Achieve a Set of Ambitious Global Sustainability Objectives by 2050: Explorations Using the IMAGE Integrated Assessment Model. Technol. Forecast. Soc. Chang. 2015, 98, 303-323. [CrossRef]

85. Wandén, S. Miljömål och andra önskemål—en studie av synergier och konflikter [Environmental Objectives and Other Wishes-A Study on Synergies and Conflicts]; Report 5747; Naturvårdsverket: Stockholm, Sweden, 2007.

86. Dalhammar, C. The Environmental Quality Objectives—Survey of Users Opinions; Report; The International Institute for Industrial Environmental Economics (IIIEE): Lund, Sweden, 2009.

87. Almgren, R.; Lundgren, L.J. 1980-Talets Stora Miljöfrågor. Naturvårdsverket Meddelande 1591. [Major Environmental Issues for the 1980s. SwEPA]; Naturvårdsverket: Stockhlm, Sweden, 1982.

88. Lindfors, A. Sustainability Solutions_Lessons on Assessment and Facilitation; Linköping Studies in Science and Technology. Licentiate Thesis No 1875; Linköping University: Linköping, Sweden, 2020; ISBN 978-91-7929-870-8.

89. Linnér, B.-O.; Wibeck, V. Sustainability Transformations. Agents and Drivers Across Societies; Cambridge University Press: Cambridge, UK, 2019; pp. 147-179. [CrossRef] 